\title{
ANALISIS EFEKTIVITAS KEBIJAKAN \\ PEMERINTAH KOTA MAKASSAR NO 15 TAHUN 2009 \\ TENTANG PERLINDUNGAN PEMBERDAYAAN PASAR \\ TRADISIONAL DAN PENATAAN PASAR MODEREN
}

\author{
Asmah \\ Universitas Sawerigading Makassar
}

\begin{abstract}
The city of Makassar is a metropolitan city with a population that each year experiences developments in terms of urbanization, considering that Makassar is the Capital of South Sulawesi Province. With a population that is increasingly dense and increasing so that it affects the needs of increasingly complex economic levels. In addition, modern retailers make a positive contribution which also has a huge social economic impact. This is because traditional markets which are generally small businesses experience setbacks due to the existence of modern retailers that are slowly but surely threatening the continuity of traditional markets. Through Regional Regulation No. 15 of 2009 concerning the protection of traditional market empowerment and modern market arrangement, it can provide regulation for both markets. The efforts made by the Makassar city government are to record and provide information on the existence and operating hours of modern markets, but the results have not been in line with the expectations of all parties in applying these regulations because the zone arrangement has not been clearly regulated. This study uses a type of empirical research with approaches related to legislation and published journals as well as taking to the field observing and interviewing respondents. The results found that the Regional Regulation No. 15 of 2009 has not been effective because it has not regulated the related zone. The problem of zones between modern markets and other modern markets and the distance between modern markets and traditional markets and not yet regulating the hours of modern market operations that led to high modern market expansion in Makassar City.
\end{abstract}

Keywords:

Policy, Protection, Modern Retail, Traditional Markets

\section{Abstrak}

Kota Makassar adalah kota metropolitan dengan jumlah penduduk yang tiap tahun mengalami perkembangan dari segi urbanisasi, mengingat Makassar sebagai Ibukota Provinsi Sulawesi Selatan. 
Dengan jumlah penduduk yang semakin padat dan meningkat sehingga berpengaruh kepada kebutuhan dari tingkat ekonomi yang semakin kompleks. Selain itu, ritel moderen memberikan kontribusi positif yang juga menimbulkan dampak sosial ekonomi yang sangat besar. Hal ini disebabkan pasar tradisional yang umumnya merupakan usaha kecil mengalami kemunduran akibat keberadaan ritel moderen yang secara perlahan tapi pasti mengancam kelangsungan pasar tradisional. Melalui Perda No 15 Tahun 2009 tentang perlindungan pemberdayaan pasar tradisional dan penataan pasar moderen dapat memberikan pengaturan bagi kedua pasar tersebut. Upaya yang dilakukan oleh pemerintah kota Makassar adalah dengan mendata dan memberikan informasi terhadap keberadaan dan jam operasional pasar moderen, namun hasilnya belum sesuai dengan harapan semua pihak dalam mengaplikasi peraturan tersebut karena pengaturan zona belum diatur secara jelas. Penelitian ini menggunakan jenis penelitian empiris dengan pendekatan yang terkait peraturan perundang-undangan dan jurnal yang telah dipublikasi serta turun ke lapangan melakukan pengamatan dan wawancara responden. Hasil yang ditemukan bahwa Perda No 15 Tahun 2009 belum berjalan efektif karena belum mengatur zona terkait. Masalah zona antara pasar moderen dan pasar moderen yang lain dan jarak antara pasar moderen dengan pasar tradisional serta belum mengatur jam operasi pasar moderen yang menyebabkan tingginya ekspansi pasar moderen di Kota Makassar.

Kata Kunci:

Kebijakan, Perlindungan, Ritel Moderen, Pasar Tradisional.

\section{A. PENDAHULUAN}

\section{Latar Belakang}

i Indonesia sebagai Negara hukum, peraturan tentang larangan praktek monopoli dan persaingan usaha tidak sehat dalam bidang perekonomian sebagaimana yang diamanatkan dalam UUD 1945.menjadi dasar adanya undang-undang No 5 Tahun 1999 dasar dari Undang - Undang ini adalah dari pasal 33 ayat (1) Undang-Undang Dasar 1945 menetapkan bahwa perekonomian disusun sebagai usaha bersama atas asas kekeluargaan. Istilah kekeluargaan seringkali ditafsirkan sebagai anti mempersaingan tetapi sebenarnya esensi dari pasal ini adalah berorientasi pada ekonomi kerakyatan.

Larangan praktek monopoli dan persaingan usaha tidak sehat dalam bidang ekonomi sebagaimana yang diamanatkan dalam Undang-Undang Dasar 1945. Telah lama dinantikan oleh masyarakat, khususnya pelaku ekonomi,baik sektor usaha menengah (UKM) atau usaha besar. Tujuannya adalah terjadi persaingan yang sehat 
dalam hal produksi, pemasaran yang bisa mengakibatkan investor domestik maupun asing tertarik menanamkan modalnya dan berinvestasi di Indonesia

Kota Makassar merupakan kota metropolitan dengan jumlah penduduk mencapai t. 1.658 .503 jiwa (Data BPS Makassar 2016-2017), hal ini menjadikan Makassar sebagai salah satu daerah dan menjadi pintu gerbang Indonesia Timur dalam hal perdagangan dan pelaku usaha, untuk kegiatan pelaku usaha kecil dan menengah, khususnya dalam pasar Moderen yang lebih di dominasi adalah retail moderen dengan fasilitas yang memadai dan mudah dijangkau oleh masyarakat dalam hal berbelanja, hal ini yang menyebabkan pasar tradisional lambat laun menjadi berkurang.

Oleh karena itu Pemerintah Kota Makassar membuat Perda No 15 Tahun 2009 dengan tujuan agar sesuai dengan Undang-Undang No 5 Tahun 1999. tentang larangan praktek monopoli dan persaingan yang tidak sehat serta Perpres No 112 Tahun 2007 yang tujuan utamanya adalah supaya terjadi perbaikan ekonomi, sehingga terjadi penyelarasan dan pemberdayaan pasar tradisional maka perlu di berdayakan agar tumbuh dan berkembang serasi, saling memerlukan, saling memperkuat serta saling menguntungkan semakin banyak pengusaha dan investor asing tertarik menanamkan modal agar tercipta lapangan kerja. Sehingga masyarakat lebih kondusif dengan upaya meningkatkan kesejahteraan rakyat.

Dalam penegakan hukum persaingan usaha memakai dua prinsip yaitu: (1) pendekatan Rule of Reason dan (2) Rule Per Se. Dipakai kedua pendekatan ini karena dalam penegakan hukum disamping ada sisi kepastian hukum juga di utamakan dalam hal keadilan yang menjadi dasar dari UU No 5 Tahun 1999 yang menjadi dasar dibentuknya UU tersebut. ${ }^{1}$

Demi menyikapi untuk menyelaraskan UU No 5 Tahun 1999 dan Perpres No 112 Tahun 2007 serta Permendag No 8 53/2008, terhadap peraturan pemerintah Kota Makassar mengeluarkan peraturan Daerah (Perda) No 15 Tahun 2009 agar efektif penggunaan perda tersebut sehingga diperlukan upaya memaksimalkan perda berjalan sesuai amanah perundang-undangan yang berlaku, agar penataan pasar moderen dan pasar tradisional bisa sesuai dengan peraturan perundang-undangan dan Perpres serta permendag yang ada selama ini.

Pada Kuliah Umum serta seminar nasional "peran KPPU dalam mendorong persaingan usaha dan etika bisnis di Indonesia, "diadakan oleh Universitas Bina Nusantara (Binus) April 2017 di Alam Sutera Jakarta. Iur Stefen Koos, bahwa dalam dunia usaha senantiasa diutamakan etika dan kesehatan bisnis bagi setiap pelaku usaha begitupun pemerintah dalam mengatur deregulasi yang baik. ${ }^{2}$

1 .Susanti Adi Nugroho, 2012, Hukum Persaingan Usaha Di Indonesia, Kencana Prenada Media Group, Jakarta, Hal 723

${ }^{2}$ Stfen Koos, "ethic in civil Business Law”, Seminar Nasional Univ Binus, 3 April 2017, KPPU, Jakarta. hal 2. 
Untuk mewujudkan hukum bisnis atau perdagangan yang adil antara peritel moderen dan pasar tradisional dibutuhkan suatu prinsip atau asas yang menjamin hak dan kepentingan kedua belah pihak, asas yang dimaksud adalah asas keseimbangan yang dapat dimengerti oleh pandangan umum yang mendambakan kedamaian dan keadilan dalam berusaha dan kesempatan yang sama. ${ }^{3}$

Banyaknya peraturan serta pengaturan menjadikan dasar dalam melihat sisi lain pada pasar tradisional dan pasar moderen, sehingga pada uraian yang di kemukakan penulis sebagai peneliti dapat memberikan gambaran tentang Keberadaan pasar moderen dan pasar tradisional bisa di lihat dalam segi pengertian sehingga bisa nampak perbedaan dan persamaan dalam kedua pasar tersebut.

Pasar tradisional merupakan tempat bertemunya penjual dan pembeli serta ditandai dengan adanya transaksi penjual dan pembeli secara langsung dan ditandai dengan ada proses tawar-menawar. Dilihat dari segi bangunan, pasar tradisional biasanya terdiri dari kios-kios atau gerai, los dan dasaran terbuka yang dibuka oleh penjual maupun pengelola pasar. Pada umumnya pasar tradisional banyak menjual kebutuhan sehari-hari seperti bahan-bahan makanan berupa ikan, buah, sayursayuran, telur, daging, kain, pakaian, barang elektronik, jasa dan lain-lain. ${ }^{4}$

Pasar moderen adalah pasar yang dibangundan dikelola oleh pemerintah, swasta, atau kperasi yang dlaam bentuknya berupa pusat perbelanjaan, seperti mall, plaza, dan shopping center serta sejenisnya dimana pengelolaannya dilaksanakan secara moderen dan mnegutamakan pelayanan kenyamanan berbelanja dengan manajemen berada di satu tangan bermodal relatif kuat dan dilengkapi dengan label harga pasti. ${ }^{5}$

Pesatnya pembangunan pasar modern dirasakan oleh banyak pihak berdampak terhadap keberadaan pasar tradisional. Di satu sisi, pasar modern dikelola secara profesional dengan berbagai fasilitas yang serba menarik. Di sisi lain, pasar tradisional masih berkutat dengan permasalahan internal seputar pengelolaan yang kurang profesional dan kekurang nyamanan ketika berbelanja. Jika pasar tradisional tidak bersiap diri menghadapi persaingan usaha dengan pasar retail modern, maka ribuan bahkan jutaan pedagang kecil akan kehilangan mata pencahariannya. Pasar tradisional mungkin akan tenggelam seiring dengan perkembangan persaingan usaha dunia retail saat ini yang didominasi oleh pasar modern.

Kehadiran pasar retail modern memang memiliki pengaruh yang cukup signifikan terhadap keberlangsungan pasar tradisional. Meskipun demikian, argumen yang mengatakan bahwa kehadiran pasar retail modern merupakan penyebab utama tersingkirnya pasar tradisional tidak sepenuhnya benar. Hampir seluruh pasar tradisional di Indonesia dan Di Kota Makassar masih bergelut dengan

\footnotetext{
3 Cindawati,"Analisi Kekuatan mengikat kontrak sebagai dasar yuidis dalam bisnis, Jurnal Arena Hukum,ISSN 01260235 , fakultas hukum Brawijaya Malang. hal 389

4 saidah sakwan, “dengan peternak dan pedagang” Kuliah Umum april 2016,, di kantor KPPU Makassar, Makassar. hal 4

${ }^{5}$ perda no 15 Tahun 2009.
} 
masalah internal pasar seperti buruknya manajemen pasar, sarana dan prasarana pasar yang sangat minim, pasar tradisional sebagai sapi perah untuk penerimaan retribusi, menjamurnya pedagang kaki lima (PKL) yang mengurangi pelanggan pedagang pasar, dan minimnya bantuan permodalan yang tersedia bagi pedagang tradisional. Keadaan ini secara tidak langsung menguntungkan pasar modern.

Menjamurnya pasar retail modern memang seperti buah simalakama dalam perekonomian suatu daerah terutama dengan adanya otonomi daerah, suatu daerah di pacu untuk meningkatkan daerahnya. Dan beberapa kalangan memandang positif bahwa makin meluasnya pendirian pasar modern di Makassar dapat memberikan pendapatan dan kemajuan suatu daerah, sehingga hampir disudut kota Makassar terdapat ritel Moderen, bahkan bisa mencapai 12 ritel Moderen dalam satu kecamatan, tapi hal ini sangat berdampak kepada pengurangan pasar tradisional yang hanya ada satu (1) pada tiap kecamatan dengan Fasilitasi yang sangat kurang memadai, dan pihak Pemerintah Daerah kurang perhatian sehingga di perlukan pengaturan dari pemerintah Kota Makasssar dalam penataannya dan penerbitannya.

Tujuan Dari Pemkot Makassar membentuk Perda No 15 Tahun 2009 tentang perlindungan dan pemberdayaan pasar tradisional dan penataan pasar moderen adalah penataan perdagangan dan usaha di Kota Makassar menjadi lebih baik dan terarah serta tidak terjadi praktek Monopoli tempat dan wilayah strategis dalam hal kegiatan usaha. Keinginan Pemerintah Kota Makassar sangat jelas untuk mengatur tidak adanya praktek monopoli dalam bidang usaha dan persaingan usaha di Makassar.

\section{Permasalahan}

Bagaimana efektivitas pelaksanaan pemerintah Kota Makassar dalam mengoptimalkan Perda No 15 Tahun 2009 tentang perlindungan pemberdayaan pasar tradisional dan penataan pasar moderen

\section{B. PEMBAHASAN}

Permasalahan Yang Dihadapi Oleh Pemkot Dalam Menyeleraskan Perda No. 15 Tahun 2009

Dalam Undang-Undang No 5 Tahun 1999 tentang larangan praktek monopoli dan persaingan usaha tidak sehat di sebutkan dalam pasal 2 pelaku usaha di Indonesia dalam menjalankan kegiatan usahanya berasakan demokrasi ekonomi dan memperhatikan keseimbangan antara kepentingan pelaku usaha dan kepentingan umum. Ada dua hal penting yang menjadi permasalahan di dalam pasal tersebut yakni pertama mengenai defenisi asas demokrasi ekonomi dan kedua mengenai defenisi kepentingan umum. Kedua hal tersebut di atas hingga kini masih menjadi permasalahan, mengingat bagian penjelasan menyatakan bahwa pasal 2 tersebut sudah jelas, sehingga di dalam praktek kedua hal tersebut masih diartikan secara multiinterpretatif. 
Dalam Perpres No 112 tahun 2007 pada pasal 4 huruf a menyebutkan pedirian pusat perbelanjaan dan toko moderen wajib memperhatiakan kondisi ekonomi masyarakat, keberadaan pasar tradisional usaha kecil dan usaha menengah yang ada diwilayah yang berdangkutan sedangkan dalam Permendag No 53/ MDAG/PER/12/2008 tentang pedoman penataan dan pembinaan pasar moderen dan pusat perbelanjaan.dalam permendag ini terkandung bahwa masalah penentuan lokasi, jam buka dan jarak lokasi outlet ritel moderen dan peraturan mengenai kemitraan, persyaratan perdagangan dan pembinaan serta pengawasan yang mnejadi fokus pada kajian penelitian ini.

Beranjak pada perundang-undangan dan perpres serta permendag diatas maka pemerintah kota makassar mengeluarkan perda no 15 tahun 2009 tentang perlindungan pemberdayaan pasar tradisional dan penataan pasar moderen dapat sejalan dan sesuai dengan peraturan perundangan yang berlaku tetapi tetap memperhatikan dari unsur keadilan dalam penataan tersebut, sehingga bisa menjadi pijakan yang positif dalam mendorong terciptanya dunia usaha yang sehat, terhindar dari praktek monopoli dan dapat meningkatkan lapangan kerja di kota makassar

Munculnya pasar moderen para ahli menyakini bahwa peningkatan ritel moderen skala besar berpengaruh positif dalam memperluas, memoderinisasi dan memperbaiki efisiensi industri ritel moderen domestik dan sekaligus meningkatkan kuantitas, kapasitas dan kualitas pemasok domestik, namun dilain pihak perlu dicermati pengaruh negatif terhadap pemasok domestik, lemahnya posisi tawar pemasok domestik terhadap pasar moderen dapat mengakibatkan perilaku yang tidak adil bagi pemasok domestik.

Hal tersebut disebabkan peritel besar mempunyai penguasaan modal maupun jalur distribusi, sehingga dapat mempengaruhi kegiatan pesaingnnya secara horizontal dan domestik seacra vertikal, sangat menarik dan menantang untuk dilakukan kajian, sampai sejauhmana kebijakan regulasi tersebut diatas berkaitan dengan persaingan, hubungan pemasok ritel moderen dan kinerja pemasoknya. ${ }^{6}$

Pertumbuhan jumlah pasar retail modern yang semakin pesat membuat persaingan usaha di bidang perdagangan semakin ketat, hal ini di sebabkan dengan adanya Peraturan Menteri Hukum dan Ham (Permenkumham Lewat Dirjen Ahu) “ Pemenkumham No 1 Tahun 2016 Tentang PT" bahwa pengurusan perijinan suatu PT untuk usaha di lakukan dan di percepat menjadi 60 menit, sehingga pelaku usaha sehingga Bagi pedagang yang tidak siap menghadapi persaingan usaha dengan menggunakan berbagai strategi pemasaran yang menarik dan manajemen yang baik, maka mereka akan tertindas atau kalah dalam persaingan usaha yang sangat ketat. Dalam sistem ekonomi pasar, aktivitas produsen dan konsumen tidak direncanakan oleh sebuah lembaga sentral, melainkan secara individual oleh pelaku

\footnotetext{
${ }^{6}$ Dedie Martadisastra,Dampak Regulasi terhadap Hubungan Ritel moderen dengan Pemasok domestik, Jurnal Persaingan Usaha, edisi 8 no issn 2087-0353 tahun 2012 hal 46, KPPU Jakarta.
} 
ekonomi. Persainganlah yang bertindak sebagai tangan-tangan tidak terlihat yang mengkoordinasikan rencana masing-masing. Sistem persaingan yang terbentuk dapat membuat produksi dan konsumsi, serta alokasi sumber daya alam, sumber daya manusia dan modal menjadi lebih efisien.

Dalam satu Contoh yang penulis teliti adalah di Kecamatan Panakukang yang merupakan sentra ekonomi dan bisnis Di Kota Makassar dengan jumlah penduduk mencapai 12 ribu jiwa dengan tingkat komsumsi dan jumlah pertumbuhan ekonomi paling menonjol dari 11 kecamatan lainnya yang ada di Kota Makassar hal ini dpaat di lihat dari banyak nya pasar Moderen antara lain : Carrepour, Hypermart, Lottemart serta ritel Moderen lain dalam skala kecil yaitu Alfamart dan Indomart dan berada di pinggir jalan strategis serta berada di posisi strategis dengan Jumlah 7 hanya berada dalam satu jalan yaitu Jalan pengayoman yang merupakan sentra bisnis kec Panakukang Kota Makassar, sedangkan pasar tradisional itu hanya ada satu dan terletak bersaing diantara pasar moderen, dalam hal salah satu yang memicu begitu mudahnya pendirian pasar pasar modern disamping itu memberikan pendapatan (income) kepada pemerintah setempat dalam hal pajak serta membiayai kebutuhan dan belanja pegawai bagi suatu wilayah atau daerah, selain itu juga pajak dari izin usaha sangat membantu pemerintah kota dalam mengatur sendiri kebutuhannya sebagai daerah otonomi. juga menghadirkan suasana perkotaan yang ada dalam suatu wilayah sehingga pemerintah kota Makassar masih perlu melakukan penataan jumlah dan strategi kepada pasar modern agar tidak mengganggu pasar tradisional yang semakin berkurang.

Di sisi lain upaya pemerintah kota makasaar dalam mengefektifkan penegakan hukum bagi perda N0 15 tahun 2009 agar sesuai dengan Undang-Undang No 5 Tahun 1999 dan peraturan Presiden No 112 Tahun 2007 bahwa pemberian izin usaha diberikan kemudahan dan fasilitas secara on line dan satu pintu, di samping itu beberapa Peratutan Menteri Perdagangan (permendag) No 53/2008 Tentang pedoman penataan dan pembinaan pasar tradisional, pasar moderen dan pusat perbelanjaan, dengan permendag ini mengamanahkan adanya perdagangan wajar dan adil, untuk itu pentaan bagi para pedagang baik pasar tradisional dan moderen. memerlukan suatu keadilan dalam berusaha dengan baik terutama warung-warung kecil sudah tidak nampak dalam suatu daerah pasar tradisional.

Penegakan hukum merupakan penerapan diskresi yang menyangkut membuat keputusan yang tidak secara ketat diatur oleh kaidah hukum, akan tetapi mempunyai unsur penilaian pribadi. Berdasarkan hal tersebut maka penegakan hukum sebenarnya terletak pada faktor-faktor yang mungkin mempengaruhinya. Faktor-faktor tersebut mempunyai arti yang netral, sehingga dampak positif atau negatifnya terletak pada isi faktor-faktor tersebut, adalah sebagai berikut. ${ }^{7}$

7 Soerjono Soekanto, faktor-faktor yang mempengaruhi penegakan hukum, Raja Grafindo Persada, jakarta. 2013 hal 8 


\section{Faktor hukumnya sendiri}

Kebijakan yang di keluarkan Pemerintah Kota Makassar agar Perda Kota Makassar No 15 tahun 2009,dapat bisa disosialisakan sehingga bisa selaras dengan Perpres No 112 tahun 2007 tentang penataan dan pembinaan pasar tradisional pusat perbelanjaan dan toko moderen, Permendag No 53/2008 serta Permenkumham No 1 Tahun 2016 Tentang PT dan kebijakan pemerintah pusat lewat kemudahan berusaha, sehingga dengan perda ini di harapkan dapat memberikan penataan dan keadilan bagi pedagang pasar tradisional dan di sisi lain dapat memberikan kemudahan dan penataan kepada pasar moderen. Tapi disisi lain Perda ini masih terdapat banyak kekurangan dalam hal penerapan dan sosialisasi nya kepada masayarakat kota makassar keberadaan perda ini dapat menjadi posisi tawar antara ritel moderen dengan pasar tradisional justru tidak maksimal dalam hal ini dpaat di lihat dengan semakin menjamurnya ritel moderen hampir ada di setiap sudut kota makassar.

Dalam pasal 8 ayat 1 perda no 15 tahun 2009 disebutkan bahwa pasar tradisional dan pasar moderen harus menyediakan tempat paskir atau area parkir yang luas serta sarana umum yang maksimal, namun disisi lain kenyataannya pasar moderen dapat membangun lahan parkir dengan leluasa dan nyaman sedangkan lahan parkir bagi pasar tradisional tidak tersedia dengan baik, begitupun dalam melakukan promosi dan sosialisasi pasar tradisional tidak pernah tersentuh dengan baik, sehingga pasar moderen dapat memberikan promosi dengan gencar sehingga masyarakat konsumen dapat melihat dnegan baik.

\section{Faktor penegak hukum}

Dalam seminar nasional Mudahnya berbisnis Di indonesia oleh kemenkumham pemateri dengan Prof Juajir Sumardi, di katakan bahwa Pemerintah sekarang ini giat menggalakkan investor asing masuk dengan memberikan kemudahan dan perizinan untuk menyamai negara-negara asean dan memperbaiki posisi Indonesia dari peringkat 91 pada tahun 2016 dalam segi perizinan usaha. ${ }^{8}$

Seminar ini mempunyai maksud agar terjadi keselarasan antara aturan pemerintah pusat dengan pemerintah daerah serta para penegak kebijakan baik di daerah maupun di pusat dengan tujuan perangkat dinas yang terkait dapat lebih paham tentang kebijakan penataan suatu tempat usaha, namun kenyataan di lapangan bahwa pemerintah kota makassar lebih menyerahkan pengurusan dan penguasaan pasar tradisional kepada PD pasar raya tanpa ada perbaikan dari segi manajemen keamanan dan kenyamanan suatu pasar.

3. Faktor sarana dan fasilitas yang mendukung penegakan hukum

Faktor ini sangat dominan karena tiap hari pasar tradisional mengalami kekuarangan disebabkan lahan dan sarana yang semakin berkurang, disamping itu antusias masyarakat pada pasar tradisional kurang disebabkan sarana dan prasarana

8 Juajir Sumardi, "Mudahnya Berbisnis Di indonesia", Seminar nasional Kemenkumham,Juli 2017, Makassar Hal 12. 
dalam pasar tradisional sangat minim. Akses sarana transportasi umum kepada pasar tradisional juga sangat minim di Kota Makassar, serta buruknya fasilitas umum seperti WC dan Sarana ibadah lainnya.

Tabel 1

Jumlah Pasar Tradisional Di Kota Makassar

\begin{tabular}{|l|l|l|l|}
\hline No & Nama Pasar Tradisional & Kecamatan & Jumlah \\
\hline 1 & Pasar Maricaya & Makassar & 1 \\
\hline 2 & Pasar Toddopuli & Panakukang & 1 \\
\hline 3 & Pasar Pa'baeng baeng & Tamalate & 1 \\
\hline 4 & Pasar Daya & Biringkanaya & 1 \\
\hline 5 & Pasar Terong & Bontoala & 1 \\
\hline 6 & Pasar Sentral Makassar & Wajo & 1 \\
\hline 7 & Pasar Butung & Wajo & 1 \\
\hline
\end{tabular}

Sumber data Empiris:Maret-Mei 2017.

Jumlah pasar tradisional di kota Makassar hanya satu per kecamatan dibanding dengan jumlah pasar moderen yang begitu menjamur hampir disudut kota makassar dengan penguasaan pangsa pasar yang sangat beragam, hal ini sering memicu kecemburuan social ditambah pasar modern memberlakukan jam operasional sampai 24 jam setiap hari dengan iming-iming harga yang sangat bervariasi dan fasilitas dan kemudahan serta kenyamanan yang di tawarkan. Sedangkan jumlah Retail Moderen Di kota Makassar Telah mencapai jumlah yang sangat banyak menurut wawancara dengan kepala Seksi ijin Dinas Perindustrian Dan perdagangan Kota Makassar di Kantor Jalan Rappocini mengatakan Jumlah ritel Moderen Di Makassar telah mencapai 120 buah yang terdiri dari 14 kecamatan se kota Makassar.

Penyebab utama kalah bersaingnya pasar tradisional dengan pasar retail modern adalah lemahnya manajemen dan buruknya infrastruktur pasar tradisional, bukan semata-mata karena keberadaan pasar retail modern. Pasar retail modern sebenarnya hanya mengambil keuntungan dari kondisi buruk yang ada pada pasar tradisional. Persoalan infrastruktur yang hingga kini masih menjadi masalah serius bagi pasar tradisional adalah bangunan dua lantai yang kurang populer di kalangan pembeli, kebersihan dan tempat pembuangan sampah yang kurang terpelihara, kurangnya lahan parkir, dan buruknya sirkulasi udara. Belum lagi ditambah semakin menjamurnya pedagang kaki lima yang merugikan pedagang yang berjualan di dalam pasar di mana mereka harus membayar penuh sewa dan retribusi. 
4. Faktor masyarakat, yakni lingkungan di mana hukum tersebut berlaku atau diterapkan

Alasan yang sering keluar dari konsumen ketika menjawab pertanyaan mengapa mereka memilih pasar retail modern, adalah karena praktis dan nyaman. Hal ini yang tentunya perlu menjadi perhatian pasar tradisional, di mana mereka seharusnya mengkondisikan pasar sebagai tempat yang nyaman, aman dan menyenangkan untuk berbelanja.

Ada beberapa strategi pasar retail modern yang semakin meraih hati konsumen, seperti fasilitas belanja yang nyaman dan menarik, diskon, hadiah dan beberapa promosi lainnya. Di antara strategi yang patut diperhatikan adalah adanya penerapan harga di bawah biaya marginal (predatory price) untuk jenis barang tertentu. Strategi menetapkan harga di bawah biaya marginal sebenarnya merupakan kegiatan yang dilarang karena akan menimbulkan persaingan usaha yang tidak sehat, selain itu ada pihak pasar ritel moderen yang membuka usaha sampai 24 jam Dalam persepsi publik tentang persaingan usaha khususnya tentang pasar moderen menyebabkan timbulnya persepsi bahwa :

1. Survei di beberapa kota besar Di Indonesia seperti Jakarta, Bandung, Surabaya, medan dan Makassar menunjukkan bahwa kepercayaan dan ketahuan dan kesukaan masyarakat terhadap pasar moderen semakin meningkat daritahun ketahun.

2. Hal yang perlu di tanamkan kepada masyarakat bahwa persaingan yang sehat dapat memicu investasi dan munculnya banyak pelaku usaha sehingga tercipta kesejahteraan. ${ }^{9}$

5. Faktor kebudayaan, yakni sebagai hasil karya cipta dan rasa yang didasarkan pada karsa manusia dalam pergaulan.

Dalam hal ini karena masyarakat perkotaan sangat menyukai perubahan dan pola hidup moderen dengan lebih senang berbelanja ke retail moderen dengan berbagai macam Alasan Masyarakat Lebih Menyukai Belanja di Retail Moderen Adalah sebagai berikut:

1. Penetapan harga di bawah biaya marginal di satu sisi akan menguntungkan konsumen dalam jangka pendek, tetapi di sisi lain akan sangat merugikan pesaing. Strategi yang tidak sehat ini pada umumnya beralasan bahwa harga yang ditawarkan merupakan hasil kinerja peningkatan efisiensi perusahaan. Oleh karena itu, hal ini tidak akan terdeteksi sampai pesaing dapat mengukur dengan tepat berapa harga terendah yang sesungguhnya dapat ditawarkan pada konsumen. Pihak yang menerapkan strategi ini akan menyerap pasar (konsumen) yang lebih besar dikarenakan berpindahnya konsumen pada

${ }^{9}$ Chandra Setiawan, 2017 Peran KPPU Dalam Mendorong persaingan usaha dan etika di Indonesia, bahan seminar nasional, Jakarta, Univ Bina Nusantara. 
penawaran harga yang lebih rendah, sementara pesaingnya akan kehilangan konsumen. Pada jangka yang lebih panjang, pelaku predatory pricing akan dapat bertindak sebagai monopolis.

2. Praktek yang pernah terjadi adalah pasar retail modern berusaha menurunkan harga untuk komoditi tertentu yang dicari konsumen di bawah biaya marginal yang juga jauh di bawah harga pasar tradisional, meskipun mereka menaikkan harga untuk komoditi lainnya $\mathrm{di}$ atas harga pasar tradisional sebagai konsekuensi dari subsidi silang. Sayangnya, konsumen tidak jeli melihat hal ini sehingga merasa ada satu barang yang murah, maka yang lainnya juga dianggap murah.

3. Persaingan usaha yang ketat antara sesama pasar retail modern semakin menguntungkan konsumen karena mereka dimanjakan dengan berbagai fasilitas kenyamanan berbelanja dan harga barang belanjaan yang lebih murah. Persaingan ini tidak hanya terdapat di kota-kota besar yang menyajikan berbagai macam pasar retail modern mulai dari minimarket, supermarket, hypermarket, hingga mall, tetapi juga terdapat di kota-kota kecil dan pedesaan. Contoh yang paling nyata adalah persaingan ketat antara Alfamart dan Indomaret yang menyajikan berbagai promo dalam bentuk hadiah, potongan harga, parkir gratis dan berbagai terobosan lainnya untuk menarik hati konsumen. Jika sudah demikian, maka pasar tradisional akan semakin ditinggalkan karena konsumen lebih tertarik dengan 'ide-ide kreatif' yang ditawarkan oleh pasar retail modern demi untuk memanjakan konsumennya.

1. Berbelanja di Ritel Moderen lebih aman higienis dan menjadi tren masyarakat perkotaan ekonomi menengah keatas

2. Tempat parkir yang luas, nyaman serta pelayanan yang maksimal

3. Semua barang yang di butuhkan berada dalam satu tempat sehingga mudah terjangkau dan dilengkapi Fasilitas Umum, Atm, Musollah, dan bersih disertai fasilitas umum untuk anak-anak dalam bermain. (Sumber data dari wawancara dengan berbagai kalangan masyarakat. Januari-Mei 2017)

Peningkatan tarif hidup masyarakat membutuhkan ketersediaan berbagai macam barang yang lengkap dari kebutuhan primer, sekunder hingga tersier. Masyarakat juga membutuhkan fasilitas pendukung dalam berbelanja sehingga mereka merasakan kenyamanan, kebebasan, keamanan, harga murah dan kualitas yang baik. Dalam banyak kasus, kenyamanan berbelanja menjadi alasan utama konsumen untuk beralih dari pasar tradisional menuju pasar retail modern. Oleh karena itu, perlu ada strategi yang serius untuk menata pasar sehingga pasar tradisional semakin terasa nyaman bagi konsumen

Kini yang dipermasalahkan bukanlah kecenderungan pertumbuhan sektor ini saja, tetapi tak terlekkan pula bahwa model pasar rakyat dalam sosoknya seperti sekarang akan menciut digantikan sosok pasar atau pengecer moderen. Namun tak berarti bahwa pasar tradisional tak memiliki hak hidup dan oleh karena itu harus 
disingkirkan dengan paksa, kita harus memiliki keberpihakan terhadap yang tak berdaya atau bermodal kecil. Setiap warga negara harus memperoleh hak atas ekonomi dan hak sosial. ${ }^{10}$

\section{METODE PENELITIAN}

Tipe penelitian yang di pakai penelitian empiris amalisis dengan menggunakan pendekatan peraturan perundang-undangan,Peraturan Presiden, Peraturan Menteri, Peraturan Daerah, sumber data yang diperoleh dari jurnal ilmiah, bahan seminar nasional dan kuliah umum yang telah di publikasikan dan data sekunder dengan melakukan wawancara, informasi, dokumentasi dan hasil pengamatan dan penelitian Untuk mendapatkan dan mengumpulkan data serta informasi yang diperlukan dalam penulisan jurnal ini, maka penulis memilih lokasi penelitian di kantor Dinas Perindustrian Dan Perdagangan Kota Makassar, serta Kantor Komisi Pengawas Persaingan Usaha (KPPU) dan di berikan surat tugas oleh LPPM Univ Sawerigading Makassar dengan No. 023/T/LPPM/VII/2017, dengan rasionalitas pemilihan sampel menggunakan purposive sampling pertimbangannya karena hemogonitas populasi sehingga penarikan sampel dalam jumlah tertentu sudah dianggap refresentatif.

\section{KESIMPULAN DAN SARAN}

\section{Kesimpulan}

Berdasarkan uraian dalam bab sebelumnya maka dapat disimpulkan sebagai berikut. Efektifvitas Pemerintah Kota Makassar Dalam mengoptimalkan Perda No 15 tahun 2009 tentang Perlindungan Pemberdayaan Pasar Tradisional dan penataan pasar modern, dengan melakukan penyelarasan denga UU No 5 Tahun 1999, Perpres No 112 Tahun 2007 dengan Permendag No 53 Tahun 2007, kebijakan yang dikeluarkan oleh pemkot makaasr agar senantiasa bisa sejalan dengan kebijakan perundang-undnagan yang ada diatasnya dapat bekerja dengan baik jika di ikuti oleh bebearap faktor penegak hukum yaitu faktor stuktur, substansi atau aparat penegak hukumnya, masyarakat itu sendiri, kebudayaan, serta sarana tidak dapat berjalan dengan baik jika kelima perangkat yang dapat mensosialisasikan serta menlaksanakan aturan tersebut tidak dpaat berjalan dengan baik. Selain itu pada aturan yang ada banyak melakukan kesalahan dan tidak sesuai dengan pasal nya tersedniri membuat perda ini ada tapi tidak berjalan sebagaimana mestinya, selain sarana serta akses masyarakat terhadap peraturan daerah sangat minim sehingga masyarakat menganggap bahwa perda ini hanya sebagai pelengkap.

\section{Saran}

Terhadap Peraturan Daerah Kota Makassar No 15 Tahun 2009 tentang perlindungan, pemberdayaaan pasar tradisional dan penataan pasar moderen dapat

\footnotetext{
${ }^{10}$ Yoyo Arifuddin, “ Jurnal Hukum Persaingan Usaha”,KPPU Edisi 1 2006, Jakarta, Hal 85.
} 
dilakukan Judicial Review ke Mahkamah Agung, terutama dalam pasal 7 yang memberikan pengecualian kepada minimarket dalam pendiriannya, dan tidak sesuai dengan Perpres no 112 tahun 2007 yang menyebut minimarket sebagai toko mode

\section{Daftar Pustaka}

Cindawati, "Analisis Kekuatan Mengikat Kontrak Sebagai Dasar Yuridis" dalam Bisnis, Jurnal Arena Hukum, ISSN 0126-0235,Volume 9, Nomor 3, 2016.

Chandra Setiawan, "Peran KPPU Dalam Mendorong Persaingan Usaha Dan Etika Bisnis Di Indonesia", 2017, Jakarta, Seminar Nasional Persaingan Usaha Dalam Perspektif Bisnis, Universitas Binus Alam Sutera.

Dedie Martadisastra, "Dampak Regulasi dan Persaingan terhadap Ritel Moderen dengan Pasar Tradisional", Jurnal Persaingan Usaha, Vol Pertama, No ISSN 20870353, Edisi 6, 2011.

Dedie Martadisastra, "Dampak Regulasi dan Persaingan Terhadap Hubungan Ritel Moderen dan Pemasok domestik", Jurnal Persaingan Usaha, Vol Pertama, No ISSN 2087-0353, Edisi 8, 2012, KPPU, Jakarta.

Juajir Sumardi, “Mudahnya Berbisnis Di Indonesia”, Seminar Nasional Juli 2017, Kemenkumham Makaassar.

Stefen Koos, "Ethic In Civil Business Law”, Jakarta, Seminar Nasional Universitas Bina Nusantara Alam Sutera.

Soeryono Soekanto, 2013, Faktor-Faktor yang Mempengaruhi Penegakan Hukum, Rajawali Pers, Jakarta.

Susanti Adi Nugroho, 2012, Hukum Persaingan Usaha, Prenada Media, Jakarta.

Yoyo Arifardhani, "Sewindu Hukum Persaingan Usaha", Vol Pertama, No ISSN 2087-0353, Edisi 1, 2006, Jakarta, Komisi Pengawas Persaingan Usaha (KPPU), Hal 85-87. 